\title{
Hormonoterapia przedoperacyjna u chorych na raka piersi
}

\author{
Sylwia Dębska-Szmich, Magdalena Krakowska, Urszula Czernek, \\ Maja Habib-Lisik, Agnieszka Zięba, Piotr Potemski
}

Przedoperacyjne leczenie systemowe u chorych na raka piersi jest stosowane w celu umożliwienia operacji oszczędzającej narząd (T3N0-1M0) lub wykonania radykalnego zabiegu u chorych z pierwotnie nieoperacyjnym guzem (T1-4N0-3M0). Przed rozpoczęciem leczenia należy przeprowadzić badania diagnostyczne mające na celu dokładne rozpoznanie histopatologiczne z oceną ekspresji receptorów hormonalnych HER2 i Ki67 oraz ustalenie zaawansowania miejscowego choroby i wykluczenie obecności przerzutów odległych. Jeżeli planowany jest zabieg oszczędzający narząd, miejsce guza należy zaznaczyć tatuażem lub metalowym klipsem.

Zgodnie z rekomendacjami Europejskiego Towarzystwa Onkologii Klinicznej (European Society of Medical Oncology — ESMO) wybór farmakoterapii przedoperacyjnej powinien być uzależniony od przewidywanej wrażliwości na leki oraz — w mniejszym stopniu — od ryzyka związanego z dużym zaawansowaniem choroby.

Osiągnięcie całkowitej remisji potwierdzonej badaniem mikroskopowym po wstępnej chemioterapii wiąże się z lepszym rokowaniem. U chorych na raka o podtypie luminalnym A (tzn. z ekspresją receptorów hormonalnych, brakiem cechy HER2 i ekspresją Ki67 mniejszą niż 14\%) oraz na raka zrazikowego z obecnością receptorów hormonalnych taka odpowiedź na chemioterapię występuje bardzo rzadko. U takich chorych, szczególnie po menopauzie, należy rozważyć włączenie hormonoterapii przedoperacyjnej. W tej grupie chorych inhibitory aromatazy wykazują większą niż tamoksyfen aktywność w zakresie zwiększenia odsetka odpowiedzi bezpośrednich i poprawy „operacyjności”. Nie ma natomiast danych co do większej korzyści z ich zastosowania w zakresie całkowitego czasu przeżycia. Hormonoterapia przedoperacyjna u chorych przed menopauzą jest przedmiotem kontrowersji. Brakuje także danych dotyczących bezpośredniego porównania skuteczności chemioterapii i hormonoterapii przedoperacyjnej.

Celem pracy jest przegląd bieżącego piśmiennictwa dotyczącego hormonoterapii przedoperacyjnej u chorych na raka piersi.

\section{Review of preoperative hormonal therapy in patients with breast cancer}

Preoperative systemic treatment in patients with breast cancer enables conserving surgery in stage T3N0-1M0 or radical mastectomy in patients with primary inoperative tumor (T1-4N0-3M0). This treatment should be preceded by an accurate histopathological diagnosis with hormonal receptors profile, HER2 testing and evaluation of Ki67 expression. Also, precise staging should be performed and distant metastases should be excluded. In cases of conserving surgery, marking the tumor with a tattoo or a metal clip is obligatory.

According to recommendations of European Society of Medical Oncology (ESMO) the choice of preoperative pharmacotherapy should rather be based on predicted cancer responsiveness to the treatment than the poor risk factors resulting from the locally advanced stage of disease.

Complete remission confirmed by pathological examination after preoperative chemotherapy correlates with better prognosis. Patients with lumenal A subtype (hormonal receptors positive, HER2-negative, Ki67 < 14\%) and hormonal

\section{Klinika Chemioterapii Nowotworów}

Uniwersytet Medyczny w Lodzi

Pracę współfinansowano ze środków Europejskiego Funduszu Społecznego i Budżetu Państwa w ramach Działania 2.6 Zintegrowanego Programu Operacyjnego Rozwoju Regionalnego, w związku z realizacją Projektu „Stypendia wspierające innowacyjne badania naukowe doktorantów” oraz z działalności statutowej nr 503/1-034-02/503-01. 
receptor-positive lobular type of breast cancer hardly ever achieve PCR. If postmenopausal they are candidates for neoadjuvant hormonal therapy. In postmenopausal patients treatment with aromatase inhibitors is more effective than with tamoxifen regarding higher response rates and improvement of surgical options. However, it is still unknown, if aromatase inhibitors in a neoadjuvant setting improve survival when compared to tamoxifen. Preoperative hormonal therapy in premenopausal patients is controversial. There are no data from studies directly comparing efficacy and safety of preoperative hormonal therapy and chemotherapy.

This paper is a review of current studies about preoperative hormonal treatment of breast cancer.

NOWOTWORY Journal of Oncology 2014; 64, 1: 40-47

Słowa kluczowe: rak piersi, przedoperacyjna hormonoterapia

Key words: breast cancer, preoperative hormonal treatment

\section{Rola leczenia przedoperacyjnego}

Zgodnie z zaleceniami Europejskiego Towarzystwa Onkologii Klinicznej (ESMO) do celów leczenia przedoperacyjnego u chorych na raka piersi należą [1]:

- umożliwienie zabiegu oszczędzającego narząd (T3NO$-1 \mathrm{M0}$ ),

- umożliwienie zabiegu u chorych z rakiem pierwotnie nieoperacyjnym lub rakiem zapalnym (T1-4N0-3M0),

- uzyskanie informacji o skuteczności leczenia i rokowaniu u chorej,

- uzyskanie informacji poszerzających wiedzę o leczeniu raka piersi (badania kliniczne).

Diagnostyka przed kwalifikacją do leczenia przedoperacyjnego powinna doprowadzić do precyzyjnego rozpoznania mikroskopowego i ustalenia zaawansowania choroby. Badanie histopatologiczne materiału pobranego zazwyczaj metodą biopsji gruboigłowej ma za zadanie określić typ histologiczny, stopień złośliwości histologicznej (grading - G), ekspresję receptorów steroidowych (ER, PR), stan receptora HER2 i ekspresję wskaźnika proliferacji Ki67.W ramach oceny zaawansowania (TNM) należy wykonać badania obrazujące stan miejscowy (mammografia, USG przed leczeniem i po leczeniu systemowym), a u chorych w Ill stopniu zaawansowania — także badania laboratoryjne, RTG klatki piersiowej, USG jamy brzusznej i miednicy oraz scyntygrafię kośćca. Należy wykonać BAC zmienionych regionalnych węzłów chłonnych. U chorych przygotowywanych do leczenia oszczędzającego należy oznaczyć miejsca z guzem tatuażem lub klipsem.

Obecnie w ramach systemowego leczenia przedoperacyjnego dysponuje się chemioterapią, hormonoterapią i leczeniem anty-HER2. Hormonoterapia ma zastosowanie u chorych z ekspresją ER/PR.

Do niedawna leczeniu przedoperacyjnemu przyświecała zasada, że potrzeba bardziej agresywnego leczenia wynika z większej liczby czynników ryzyka (większego zaawansowania). Przez bardziej agresywne leczenie rozumiano chemioterapię. Według najnowszych zaleceń, wybierając farmakoterapię, należy kierować się przede wszystkim przewidywaną wrażliwością komórek nowotworowych na leki.

\section{Ograniczona wartość chemioterapii u chorych z podtypem luminalnym}

Badania z ostatnich lat pokazały, że całkowita remisja nowotworu potwierdzona mikroskopową analizą materiału (pathologic complete response - pCR) pooperacyjnego jest wyznacznikiem dobrej odpowiedzi na zastosowaną chemioterapię i wiąże się z lepszym rokowaniem u chorych na raka piersi. Odsetki 5-letnich przeżyć całkowitych u chorych po przedoperacyjnej chemioterapii wg programu FAC, które uzyskały i nie uzyskały pCR, wynosiły odpowiednio 89\% i 64\%, p =0,003 [2].

Dodanie taksoidów do chemioterapii opartej na antracyklinach zwiększa 2-krotnie odsetek pCR. Sekwencyjne stosowanie antracyklin i taksoidów wydaje się skuteczniejsze niż ich skojarzenie, umożliwia uzyskanie pCR u 14-28\% chorych [3-6].

Intensywne badania pozwoliły także zidentyfikować czynniki predykcyjne odpowiedzi na chemioterapię neoadiuwantową. W tabeli I umieszczono przykłady cech związanych z wrażliwością na cytostatyki [6-12].

Szczególnie interesująca jest praca Sikova i wsp. [12], w której oceniono odsetek pCR po chemioterapii przedoperacyjnej (karboplatyna (AUC 6) + paklitaksel $80 \mathrm{mg} / \mathrm{m}^{2} \mathrm{q} 1$ $w$ (16 tyg.) \pm trastuzumab) u chorych na raka piersi w zaawansowaniu IIA-IIIB z różnym profilem ekspresji ER, PR i HER2. Badanie ukazało, że chore na raka hormonozależnego, szczególnie ER/PR+ HER2-, znacznie rzadziej osiągają pCR po wstępnej chemioterapii w porównaniu z chorymi na raka potrójne ujemnego czy HER2+.

Obserwacja ta jest tym bardziej interesująca, że na podstawie profilu receptorowego w najnowszych zaleceniach ESMO wyróżniono podtypy raka piersi [13]. Immunohistochemiczna (fenotypowa) klasyfikacja uwzględnia ekspresję ER, PR, HER2 i wskaźnik proliferacji Ki67. Wyróżnia ona następujące podtypy raka piersi:

— luminalny A (ER/PR+, Ki67 < 14\%, HER2-),

- liminalny B (ER/PR+, Ki67 > 14\%, HER2-),

- luminalny HER2-zależny (ER/PR+, Ki67 każdy, HER2+),

- HER2-zależny (ER/PR-, Ki67 każdy, HER2+),

- potrójnie ujemny/podstawny (ER/PR-, Ki67 każdy, HER2-). 
Tabela I. Biomarkery związane z odpowiedzią na chemioterapię przedoperacyjną

\begin{tabular}{ll}
\hline Badanie & Biomarkery związane z większym odsetkiem pCR \\
\hline Green 2005 & Brak ekspresji ER i PR \\
Prisack 2005 & $\begin{array}{l}\text { Większy stopień złośliwości histologicznej, większa ekspresja Ki67, mniejsza ekspresja ER/ PR, mniejsza ekspresja Bcl2, } \\
\text { ekspresja HER1 }\end{array}$ \\
von Minckwitz 2002 & Brak klinicznie zajętych pachowych węzłów chłonnych, cecha G3, brak ekspresji ER i PR, brak ekspresji Bcl2 \\
Zhou 2008 & Brak ekspresji ER i PR, obecność cechy HER2 \\
GEPARTRIO Rody 2006 & Obecność cechy HER2 \\
Burcombe 2005 & Zmniejszenie ekspresji Ki67 po chemioterapii neoadiuwantowej o > 75\% \\
Sikov 2009 & Odsetki pCR u chorych z różnym profilem receptorowym \\
& HER2+ (76\%) v. HER2- (31\%) p =0,003 \\
& ER- (75\%) v. ER+ (27\%) $p=0,001$ \\
& TNBC (67\%) v. ER+HER2- (12\%) p=0,002
\end{tabular}

$\mathrm{pCR}$ — całkowita odpowiedź potwierdzona mikroskopowo; ER — receptory estrogenowe; PR — receptory progesteronowe; TNBC — potrójnie ujemny rak piersi; "-" - brak ekspresji ${ }_{\prime \prime}+"$ - obecna ekspresja

Tabela II. Odsetek pCR uzyskanych po przedoperacyjnej chemioterapii u chorych z różnymi podtypami raka piersi

\begin{tabular}{|c|c|c|c|c|}
\hline Badanie & Użyta metoda & Liczba chorych & Wyniki odsetek uzyskanych pCR & \\
\hline Rouzier 2005 & $\begin{array}{l}\text { Genotypowanie } \\
\text { Affymetrix U133A }\end{array}$ & 82 & $\begin{array}{l}\text { Lum A/B } \\
\text { HER2+ } \\
\text { Podstawny }\end{array}$ & $\begin{array}{l}7 \% \\
45 \% \\
45 \%\end{array}$ \\
\hline Parker 2009 & $\begin{array}{l}\text { Genotypowanie } \\
\text { PAM50 }\end{array}$ & 347 & $\begin{array}{l}\text { Lum A } \\
\text { Lum B } \\
\text { HER2+ } \\
\text { Podstawny }\end{array}$ & $\begin{array}{l}7 \% \\
17 \% \\
36 \% \\
43 \%\end{array}$ \\
\hline Chang 2010 & $\mathrm{IHC}$ & 74 & $\begin{array}{l}\text { HR+/HER2- } \\
\text { HER2+ (leczone chemioterapią i trastuzumabem) } \\
\text { HER2+ (leczone tylko chemioterapią) } \\
\text { TNBC }\end{array}$ & $\begin{array}{l}19,4 \% \\
40 \% \\
7,1 \% \\
54,6 \%\end{array}$ \\
\hline Fasching 2011 & $\mathrm{IHC}$ & 547 & $\begin{array}{l}\text { HR+HER2- Ki67 < 38\% } \\
\text { HR+HER2- Ki67 > 38\% } \\
\text { HR+ lub HER2+ (leczone chemioterapią i trastuzumabem) } \\
\text { HR+ lub HER2+ (leczone tylko chemioterapią) } \\
\text { TNBC }\end{array}$ & $\begin{array}{l}3 \% \\
18,9 \% \\
52 \% \\
28,8 \% \\
47,3 \%\end{array}$ \\
\hline Staver 2010 & $\mathrm{IHC}$ & 254 & $\begin{array}{l}\text { HR+HER2- } \\
\text { HER2+ (leczone chemioterapią i trastuzumabem) } \\
\text { HER2+ (leczone tylko chemioterapią) } \\
\text { TNBC }\end{array}$ & $\begin{array}{l}2 \% \\
35 \% \\
8 \% \\
28 \%\end{array}$ \\
\hline
\end{tabular}

pCR — całkowita odpowiedź potwierdzona mikroskopowo; Lum — luminalny; HR — receptory hormonalne; IHC — badanie immunohistochemiczne; TNBC — potrójnie ujemny rak piersi

Nazwy podtypów zaadaptowano z klasyfikacji genotypowej stworzonej 10 lat temu na podstawie ekspresji wybranych genów [14] charakterystycznych dla komórek, z których wywodzą się poszczególne podtypy nowotworu (luminalnych, podstawnych). Jakkolwiek klasyfikacje fenotypowa (immunohistochemiczna) i genotypowa operują tymi samymi nazwami, nie są tożsame i tylko częściowo nakładają się na siebie.

Cytowana wyżej praca Sikova i wsp. pokazuje zatem, że różne podtypy raka piersi są różnie wrażliwe na chemioterapię, co mierzone jest odsetkiem całkowitych remisji potwierdzonych badaniem mikroskopowym. Obserwację tę potwierdziły liczne badania, których przykłady przedstawiono w tabeli Il [15-19]. Niezależnie od tego, czy zdefiniowany jest na podstawie ekspresji receptorów czy genotypowania, podtyp luminalny raka piersi, szczególnie luminalny $A$, charakteryzuje się ograniczoną wrażliwością na chemioterapię, a chore poddane przedoperacyjnej chemioterapii znacznie rzadziej osiągają pCR niż chore z innymi podtypami nowotworu.

Wspomniano wcześniej, że osiągnięcie pCR po chemioterapii przedoperacyjnej wiąże się z istotnym polepszeniem rokowania w porównaniu z brakiem pCR. Okazuje się, że obserwacja ta dotyczy przede wszystkich chorych na raka potrójnie ujemnego lub HER2-zależnego. Wg Faschinga i wsp. [18] u chorych z fenotypem ER/PR+ HER2- osiągnięcie lub brak pCR po wstępnej chemioterapii nie wpływa na odsetek 5-letnich przeżyć całkowitych. Zatem chore ER/PR+ 
Tabela III. Skuteczność tamoksyfenu w leczeniu przedoperacyjnym u chorych na raka piersi

\begin{tabular}{lll}
\hline Badanie & Metody, uwagi & Wyniki \\
\hline Bergman 1995 & $\begin{array}{l}\mathrm{N}=85 \text {, wiek }>75 \text { rż. } \\
\text { TAM jako jedyne leczenie, ratunkowa chir./ } \\
\text { /RT w razie PD, brak oceny ER }\end{array}$ & CR $=14,1 \%, \mathrm{PR}=23,5 \%$ \\
& $\mathrm{~N}=161$, wiek $>70$ rż., TAM & ORR $=61 \%, \mathrm{CR}=27 \%$ \\
Bradbeer 1983 & $\mathrm{N}=235$, wiek $>70$ rż., TAM & CR $-9,2 \%$, PR $-32,4 \%$, SD $-54,8 \%$, \\
Mustacchi 2003, GRETA & Opak oceny ER & med. czasu do uzyskania najlepszej odpowiedzi $-5,1$ mies. \\
& & \\
\hline
\end{tabular}

N - liczba chorych; TAM — tamoksyfen; chir. — leczenie chirurgiczne; RT — radioterapia; CR — całkowita odpowiedź; PR — częściowa odpowiedź;

ORR — odsetek obiektywnych odpowiedzi; SD — stabilizacja; ER — receptory estrogenowe

Tabela IV. Porównanie skuteczności hormonoterapii przedoperacyjnej inhibitorami aromatazy i tamoksyfenem u chorych na raka piersi po menopauzie

\begin{tabular}{|c|c|c|}
\hline Badanie & Metody & Wyniki \\
\hline $\begin{array}{l}\text { IMPACT } \\
\text { Smith } 2005\end{array}$ & $\begin{array}{l}\text { Rak operacyjny i miejscowo zaawansowany ER+ } \\
\text { odsetek chorych HER } 2+14 \% \\
\text { HT przez } 3 \text { mies. } \\
\text { A }(n=113) \text { v. T }(n=108) \text { v. } A+T(n=109)\end{array}$ & $\begin{array}{l}\text { ORR (ocenione w USG): } A-24 \% \text { v. T }-20 \% \text { v. A+T }-28 \% \text { (NS) } \\
\text { cCR (ocenione w USG): A-0 v. T-1 v. A+T-0 } \\
\text { Poprawa "operacyjności": A }-46 \% \text { v. T }-22 \% \text { v. A+T }-26 \% ; p=0,03 \\
\text { Chore HER2+: ORR A }-58 \% \text { v. T }-22 \% \text { v. A+T }-31 \%(p=0,18)\end{array}$ \\
\hline $\begin{array}{l}\text { PROACT } \\
\text { Cataliotti } 2006\end{array}$ & $\begin{array}{l}\text { Rak operacyjny i miejscowo zaawansowany, ER+ } \\
\text { HT przez } 3 \text { mies. } \\
\text { A }(n=163) \text { v. } T(n=151)\end{array}$ & $\begin{array}{l}\text { ORR (ocenione w USG): } A-36,2 \% \text { v. T }-26,5 \% ; p=0,07 \\
\text { Poprawa "operacyjności": } A-43 \% \text { v. T }-30,8 \% ; p=0,04\end{array}$ \\
\hline $\begin{array}{l}\text { P024 } \\
\text { Ellis 2001, } 2007\end{array}$ & $\begin{array}{l}\text { Rak operacyjny i miejscowo zaawansowany, ER+ } \\
\text { odsetek chorych HER } 1 / \text { HER } 2+15 \% \\
\text { HT przez } 4 \text { mies., } \\
L(n=154) \text { v. } T(n=170)\end{array}$ & $\begin{array}{l}\text { ORR }: L-55 \% \text { v. } T-36 \%, p<0,001 \\
\text { cCR: } L-10 \% \text { v. } T-4 \% \\
\text { BCS: } L-45 \% \text { v. } T-35 \% ; p=0,022 \\
\text { Odpowiedź u chorych HER1/HER2+: } L-88 \% \text { vs. } T-21 \%\end{array}$ \\
\hline Mustacchi 2009 & $\begin{array}{l}\text { Badanie Il fazy } \\
\text { operacyjny rak piersi, > } 70 \text { rż. } \\
\mathrm{N}=117 \\
\text { Exe } 25 \mathrm{mg} / \mathrm{d} \text { przez } 6 \text { mies. }\end{array}$ & $\begin{array}{l}\text { ORR po } 3 \text { mies.: } 44,7 \% \\
\text { ORR po } 6 \text { mies.: } 69,6 \% \text {, SD 23,2\%, PD 7,1\% } \\
\text { CR }-1 \% \\
\text { pCR }-0 \\
\text { BCS }-52 \% \text { (wśród nich u } 85 \% \text { poprawa „operacyjności") }\end{array}$ \\
\hline
\end{tabular}

ER — receptory estrogenowe; HT — hormonoterapia; A — anastrozol; T — tamoksyfen; ORR — odsetek odpowiedzi obiektywnych; NS — różnica nieistotna statystycznie; USG — badanie ultrasonograficzne; L — letrozol; BCS — chirurgiczne leczenie oszczędzające; Exe - eksemestan; CR — odpowiedź całkowita; cCR — odpowiedź całkowita oceniona klinicznie; pCR — odpowiedź całkowita potwierdzona mikroskopowo; SD — stabilizacja choroby; PD — progresja choroby

HER2- bardzo rzadko osiągają pCR po chemioterapii neoadiuwantowej, ale prawdopodobnie w tej grupie osiągnięcie pCR nie jest wyznacznikiem lepszego rokowania, albo też brak pCR - gorszego.

Z ograniczoną wrażliwością na chemioterapię wiąże się nie tylko podtyp luminalny, ale także zrazikowy typ histopatologiczny. Staver i wsp. [19] włączyli do swego badania 254 chore na operacyjnego raka piersi, które poddano wstępnej chemioterapii. pCR osiągnięto u 23 (12\%) spośród 195 chorych na raka przewodowego, a tylko u 1 (2\%) z 42 chorych na raka zrazikowego. Należy jednak pamiętać, że większość chorych na raka zrazikowego reprezentuje podtyp luminalny A. W badaniu Junga i wsp., do którego włączono prawie 3 tys. chorych, 91,4\% (74/83) chorych na raka zrazikowego reprezentowało podtyp luminalny $A$, podczas gdy u chorych na raka przewodowego odsetek ten wynosił 51,2\% (1088/2833) [20].

\section{Rola hormonoterapii przedoperacyjnej u chorych po menopauzie}

Na podstawie przytoczonych danych można spodziewać się, że chore z podtypem luminalnym A raka piersi charakteryzują się ograniczoną wrażliwością na chemioterapię przedoperacyjną. Czy także oznacza to, że zwłaszcza pacjentki po menopauzie odniosłyby większą korzyść z hormonoterapii?

Tabela III pokazuje przykłady badań, które oceniały skuteczność wstępnego leczenia z zastosowaniem tamoksyfenu [21-23]. Większość z tych publikacji ukazała się dość dawno. Do badań tych włączono chore w podeszłym wieku (> 70 r.ż.), dla części z nich hormonoterapia tamoksyfenem stanowiła jedyną terapię i alternatywę dla obciążającego leczenia chirurgicznego i chemioterapii. Niestety, u chorych tych nie zawsze oznaczano ekspresję receptorów hormonalnych, niemniej badania te dowodzą, że tamoksyfen jest aktywnym lekiem i umożliwia uzyskanie klinicznych całkowitych i częściowych remisji u znaczącego odsetka chorych.

Nowsze badania skupiają się na porównaniu skuteczności tamoksyfenu i inhibitorów aromatazy (IA) w ramach hormonoterapii przedoperacyjnej. Publikacje te podsumowano w tabeli IV. Do badań tych włączono chore po menopauzie z potwierdzoną ekspresją receptorów hormonalnych. Menopauza definiowana jest jako wiek powyżej 60 lat albo stan po obustronnej adneksektomii, albo brak krwawienia 
miesięcznego $\geq 12$ mies. u chorych młodszych niż 60 lat z zachowaną macicą, albo poziomem FSH > 20 U/L u chorych młodszych niż 60 lat po wcześniejszej hysterektomii. Hormonoterapia przedoperacyjna tylko u pojedynczych chorych umożliwiła uzyskanie pCR. U chorych obserwowano całkowite lub częściowe remisje potwierdzone badaniem klinicznym lub obrazowym. Zarówno tamoksyfen, jak i IA były lekami aktywnymi w tej grupie chorych. Natomiast IA umożliwiły uzyskanie obiektywnych odpowiedzi i,„poprawę operacyjności" (tzn. mastektomię u chorych z wyjściowo nieoperacyjnym nowotworem, a leczenie oszczędzające u chorych kwalifikujących się do mastektomii) u istotnie większego odsetka chorych niż w przypadku zastosowania tamoksyfenu [24-27].

Obecnie dostępnych jest kilka leków grupy IA. Badanie ACOSOG Z1031 [28] miało porównać skuteczność anastrozolu (A), letrozolu (L) i eksemestanu (Exe) w ramach 4-miesięcznego leczenia przedoperacyjnego. Do badania włączono 374 chore po menopauzie w II i III st. zaawansowania i ekspresją ER+ (w klasyfikacji Allreda wskaźnik 6-8). Zaobserwowano podobną skuteczność leków zarówno w zakresie odsetka klinicznych odpowiedzi obiektywnych (Exe - 62,9\%, L - 74,8\%, A - 69,1\%), jak i umożliwienia zabiegów oszczędzających (Exe - 67,8\%, L - 60,8\%, A - 77\%).

\section{Hormonoterapia przedoperacyjna u chorych przed menopauza}

Cytowane publikacje skupiają się na roli hormonoterapii przedoperacyjnej u chorych po menopauzie. Niestety, ciągle istnieje bardzo mało danych dotyczących takiego leczenia u chorych na raka piersi przed menopauzą. Do badania Gazeta i wsp. (29) włączono 13 chorych przed menopauzą z potwierdzoną ekspresją ER i o zaawansowaniu T1-4, N0-2. Zakwalifikowano je do przedoperacyjnej 3-miesięcznej hormonoterapii gosereliną 3,75 mg/mies. (następnie 18 mies. hormonoterapii po operacji). $\mathrm{W}$ razie progresji zmieniano leczenie na chemioterapię. U 7 chorych uzyskano odpowiedź obiektywną, u 4 - stabilizację, a u 2 doszło do progresji w trakcie leczenia hormonalnego. Z kolei do badania Torrisi i wsp. [30] włączono 32 chore przed menopauzą (ER+, T2-4 N0-2), które w ramach leczenia przedoperacyjnego otrzymały skojarzenie letrozolu i analogu gonadoliberyny. U 16 chorych uzyskano obiektywną odpowiedź, u 16 - stabilizację. U 15 z nich wykonano oszczędzający zabieg chirurgiczny. Po zabiegu operacyjnym 22 chore otrzymały adiuwantową chemioterapię opartą na antracyklinach, a 10 - hormonoterapię. Mediana obserwacji wynosiła 36 miesięcy. W tym czasie zaobserwowano 7 nawrotów i 2 zgony.

Problemowi przedoperacyjnej hormonoterapii częściowo poświęcone jest także badanie GEICAM Alby i wsp. [31]. Do badania włączono chore na operacyjnego luminalnego raka piersi (ER+/PR+/HER2-/CK8/18+), z których 51 było przed menopauzą. W ramach leczenia przedoperacyjnego u 24 kobiet zastosowano chemioterapię $(4 \times \mathrm{EC}+4 \times \mathrm{T})$, a u 27 - hormonoterapię eksemestanem i gosereliną przez 24 tygodni. Obiektywną odpowiedź uzyskano u istotnie większego odsetka chorych poddanych chemioterapii niż hormonoterapii (chemioterapia - 18/24 v. hormonoterapia $-12 / 27, p=0,027)$.

Cytowane wyżej badania obejmowały jednak bardzo małe grupy chorych. Nie oceniono w nich czynników predykcyjnych hormonoterapii innych niż stan ER+. Na podstawie powyższych danych nie ma możliwości sformułowania zaleceń co do wartości hormonoterapii przedoperacyjnej u chorych przed menopauzą.

\section{Porównanie skuteczności chemioterapii i hormonoterapii przedoperacyjnej}

Cytowane wyżej badanie GEICAM porównuje skuteczność chemioterapii i hormonoterapii przedoperacyjnej [31]. Do badania włączono nie tylko chore przed menopauzą, ale także po menopauzie, łącznie 95 chorych na operacyjnego luminalnego raka piersi.

Zaobserwowano trend w kierunku nieco większego odsetka odpowiedzi obiektywnych w całej grupie chorych leczonych chemioterapią w porównaniu z hormonoterapią przedoperacyjną, aczkolwiek różnica nie była istotna statystycznie (chemioterapia - 66\% v. hormonoterapia - 48\% $p=0,075)$. Analiza podgrup wyróżnionych na podstawie ekspresji Ki67 w komórkach nowotworowych ukazała porównywalną skuteczność obu metod leczenia, ale mniejszą toksyczność hormonoterapii u chorych z rakiem luminalnym i Ki67<10\% (chemioterapia - 63\% v. hormonoterapia $-58 \% \mathrm{p}=0,74)$.

Różne metody przedoperacyjnego leczenia farmakologicznego porównano także w badaniu retrospektywnym Ambrosa i wsp. [32]. Spośród 151 chorych po menopauzie prezentujących profil receptorowy ER+HER2- leczonych w przeciągu 13 lat w jednym ośrodku $-57 \%$ otrzymało chemioterapię, a 43\% - hormonoterapię. Chemioterapia przedoperacyjna okazała się być istotnie skuteczniejsza w zakresie uzyskania obiektywnych odpowiedzi w porównaniu z hormonoterapią (chemioterapia $-77,9 \% \mathrm{v}$. hormonoterapia $-60 \% p=0,017$ ), natomiast wynik ten nie przełożył się na rokowanie, gdyż mediany przeżycia wolnego od nawrotu w obu grupach nie różniły się istotnie statystycznie (chemioterapia $-8,5$ lat $v$. hormonoterapia -6 lat $p=0,946)$.

Prospektywnym badaniem poświęconym powyższemu zagadnieniu jest praca Semiglazova i wsp. [33]. U 121 chorych po menopauzie z ekspresją ER i zaawansowaniu T2-4N0-2 włączono hormonoterapię eksemestanem lub anastrozolem przez 3 mies. lub chemioterapię (doksorubicyna $60 \mathrm{mg} / \mathrm{m}^{2}+$ paklitaksel $200 \mathrm{mg} / \mathrm{m}^{2}$ co 3 tygodnie $4 \times$ ). 


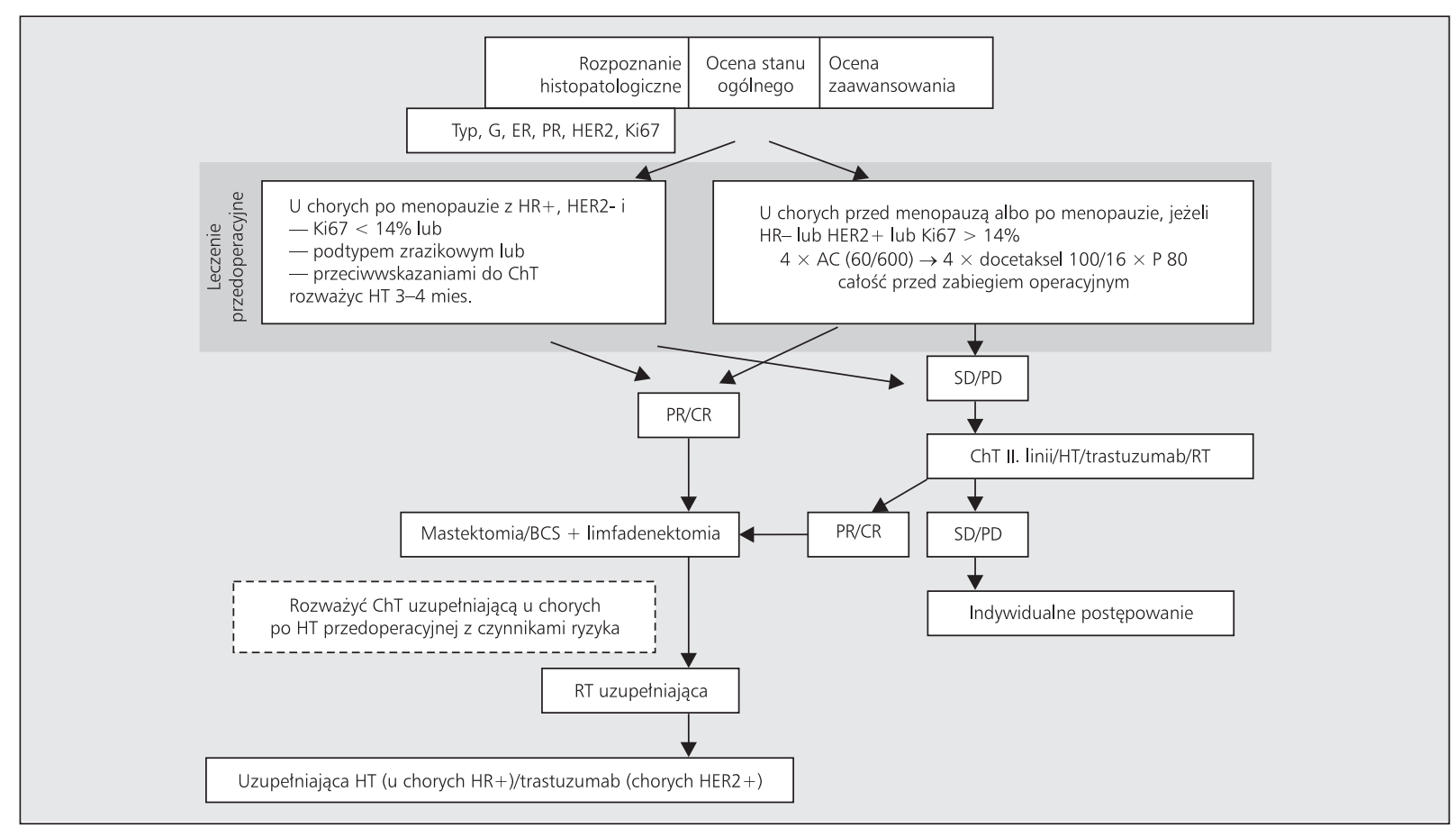

Rycina. 1. Podsumowanie zaleceń co do leczenia przedoperacyjnego u chorych na raka piersi. G — stopień złośliwości histologicznej; ER — receptory estrogenowe; PR — receptory progesteronowe; AC — doksorubicyna + cyklofosfamid; P — paklitaksel; PR — częściowa odpowiedź; CR — całkowita odpowiedź; SD — stabilizacja; PD — progresja; ChT — chemioterapia; HT — hormonoterapia; RT — radioterapia; BCS - operacyjne leczenie oszczędzające

W obu grupach odnotowano brak istotnych różnic w zakresie odsetka pCR (hormonoterapia - 3\%, chemioterapia - 6\%), odpowiedzi klinicznych (hormonoterapia - 64\%, chemioterapia - 63\%) i zabiegów oszczędzających (hormonoterapia -33\%, chemioterapia - 24\%). Przy podobnej skuteczności hormonoterapia była leczeniem mniej toksycznym. Trzeba jednak pamiętać, że zastosowana $w$ badaniu chemioterapia była nieoptymalna. Obecnie standardem przedoperacyjnego leczenia farmakologicznego jest sekwencyjne zastosowanie antracyklin i taksoidów (paklitaksel powinien być podawany co tydzień), które zapewnia najwyższy odsetek pCR [3-6].

\section{Jak oceniać rokowanie u chorych poddanych HT przedoperacyjnej?}

Osiągnięcie po chemioterapii przedoperacyjnej całkowitej remisji guza piersi i pachowych węzłów chłonnych potwierdzonej w badaniu mikroskopowym jest wykładnikiem dobrego rokowania. Jednak u chorych na raka hormonozależnego, niezależnie od sposobu leczenia przedoperacyjnego (chemioterapia lub hormonoterapia) pCR obserwowana jest bardzo rzadko i nie udowodniono, aby jej osiągnięcie miało wpływ na przeżycie [18]. Dlatego trwają badania nad ustaleniem czynników, które wiązałyby się z rokowaniem u chorych poddanych przedoperacyjnej hormonoterapii.

Zagadnieniu temu poświęcona jest praca Ellisa i wsp. [34]. Do analizy włączono chore z omawianych wyżej badań oceniających skuteczność hormonoterapii przedope- racyjnej P024 i IMPACT. W materiale pooperacyjnym po wstępnej hormonoterapii oceniono wielkość guza pierwotnego, stan pachowych węzłów chłonnych i ekspresję Ki67 i ER — wszystkie te cechy w analizie wieloczynnikowej były istotnie statystycznie związane z przeżyciem wolnym od nawrotu i przeżyciem całkowitym. Na podstawie tych informacji badacze zaprojektowali zintegrowany model biomarkerowy o wartości prognostycznej dla odległego przeżycia (PEPI — preoperative endocrine prognostic index). Dla wszystkich istotnych czynników ryzyka ponownie przeanalizowano ich hazardy względne, którym przypisano wartość punktową analogicznie jak w modelu prognostycznym dla chorób sercowo-naczyniowych. Ostatecznie stworzono 3-stopniowy model wyróżniający chore o dobrym (PEPI 0), pośrednim (PEPI 1-3) i złym (PEPI $\geq 4$ ) rokowaniu. Po 6 latach obserwacji dla chorych z poszczególnych grup odnotowano różne odsetki przeżycia wolnego od nawrotu (odpowiednio $90 \%$ v. $77 \%$ v. 52\%, p < 0,001) i przeżycia całkowitego specyficznego dla raka piersi (odpowiednio $98 \%$ v. $89 \%$ v. $83 \%, p<0,001)$. Autorzy podkreślają, że model może mieć wartość w identyfikowaniu chorych, które odniosłyby korzyść z uzupełniającej chemioterapii po przebyciu przedoperacyjnej hormonoterapii.

Cytowane wyniki wymagają potwierdzenia, by mieć zastosowanie w szerokiej praktyce klinicznej.

Można jednak na ich podstawie przypuszczać, że cechy pT1, pN0, Ki67 < 3\%, ER — wskaźnik Allreda $\geq 3$ stwierdzone 
w raporcie histopatologicznym po zabiegu operacyjnym po neoadiuwantowej hormonoterapii wiążą się z bardzo dobrym rokowaniem i takie chore prawdopodobnie nie wymagają uzupełniającej chemioterapii i nie odniosłyby z niej korzyści.

\section{Wnioski}

Na podstawie aktualnych badań wydaje się, że u chorych z podtypem luminalnym A (ER+/HER2-/Ki67 < 14\%) chemioterapia przedoperacyjna jest mniej skuteczna niż u chorych z innymi podtypami raka piersi. Hormonoterapia u tych chorych wykazuje skuteczność porównywalną z chemioterapią, a obarczona jest mniejszą toksycznością. Kandydatkami do neoadiuwantowej hormonoterapii są zatem chore po menopauzie z ekspresją receptorów steroidowych, brakiem ekspresji HER2 i ekspresją Ki67 < 14\% lub typem zrazikowym raka piersi oraz chore z przeciwwskazaniami do chemioterapii. Leczenie przedoperacyjne powinno trwać 3-4 mies.

Wnioski z niniejszej pracy, na podstawie których wydaje się możliwe sformułowanie zaleceń co do postępowania u chorych wymagających leczenia przedoperacyjnego, przedstawiono na rycinie 1.

Brakuje wiarygodnych danych co do skuteczności stosowania hormonoterapii przedoperacyjnej u chorych przed menopauzą, a z pewnością nie udowodniono jej wyższości nad chemioterapią. Chore po menopauzie odnoszą większą korzyść z zastosowania inhibitorów aromatazy (IA) w leczeniu przedoperacyjnym w porównaniu z tamoksyfenem w zakresie zwiększenia odsetka odpowiedzi bezpośrednich i poprawy „operacyjności”. Nie wiadomo natomiast, czy korzyść $z$ ich zastosowania w ramach leczenia przedoperacyjnego przekłada się na wydłużenie całkowitego czasu przeżycia. W chwili obecnej (23 grudnia 2013) leki te refundowane są w ramach hormonoterapii I rzutu u chorych na wczesnego raka piersi lub w hormonoterapii II rzutu.

\section{Konflikt interesu:}

Sylwia Dębska-Szmich — honorarium za wykład od firmy AstraZeneca - wrzesień 2012

Piotr Potemski - honorarium za wykład od firmy Astra Zeneca - wrzesień 2012

\section{Dr n. med. Sylwia Dębska-Szmich}

Klinika Chemioterapii Nowotworów Uniwersytet Medyczny w Łodzi Szpital Specjalistyczny im. Kopernika ul. Paderewskiego 4, 93-509 Łódź e-mail:sylwia.debska@o2.pl

Otrzymano: 1 maja $2013 \mathrm{r}$.

Przyjęto do druku: 1 sierpnia $2013 \mathrm{r}$.

\section{Piśmiennictwo}

1. Cardoso F, Harbeck N, Fallow L i wsp. Locally recurrent or metastatic breast cancer: ESMO Clinical Practice Guidelines for diagnosis, treatment and follow-up. Ann Oncol 2012; 23 Suppl. 7: 11-19.
2. Kuerer HM, Newman LA, Smith TL i wsp. Clinical course of breast cancer patients with complete pathologic primary tumor and axillary lymph node response to doxorubicin-based neoadjuvant chemotherapy.J Clin Oncol 1999; 17: 460-469.

3. Rastogi P, Anderson SJ, Bear HD i wsp. Preoperative chemotherapy: updat es of National Surgical Adjuvant Breast and Bowel Project Protocols B-18 and B-27. J Clin Oncol 2008; 26: 778-785.

4. von Minckwitz G, Raab G, Caputo A i wsp. Doxorubicin with cyclophosphamide followed by docetaxel every 21 days compared with doxorubicin and docetaxel every 14 days as preoperative treatment in operable breast cancer: the GEPARDUO study of the German Breast Group. J Clin Oncol 2005; 23: 2676-2685.

5. Untch M, Konecny $\mathrm{G}$, Ditsch N i wsp. Dose-dense sequential epirubicin-paclitaxel as preoperative treatment of breast cancer: results of a randomised AGO study. Proc Am Soc Clin Oncol 2002; 21 (abstr 133).

6. Green MC, Buzdar AU, Smith T i wsp. Weekly paclitaxel improves pathologic complete remission in operable breast cancer when compared with paclitaxel once every 3 weeks. J Clin Oncol 2005; 23: 5983-5992.

7. Prisack HB, Karreman C, Modlich O i wsp. Predictive biological markers for response of invasive breast cancer to anthracycline/cyclophosphamide-based primary (radio-) chemotherapy. Anticancer Res 2005; 25: 4615-4621.

8. von Minckwitz G, Sinn HP, Raab G i wsp. Clinical response after two cycles compared to HER2, Ki-67, p53, and bcl-2 in independently predicting a pathological complete response after preoperative chemotherapy in patients with operable carcinoma of the breast. Breast Cancer Res 2008; 10: R30.

9. Zhou B, Yang DQ, Xie F: Biological markers as predictive factors of response to neoadjuvant taxanes and anthracycline chemotherapy in breast carcinoma. Chin Med J 2008; 121: 387-391.

10. Rody A, Karn T, Gätje Ri wsp. Gene expression profiling of breast cancer patients treated with docetaxel, doxorubicin, and cyclophosphamide within the GEPARTRIO trial: HER-2, but not topoisomerase II alpha and microtubule-associated protein tau, is highly predictive of tumor response. Breast 2007; 16: 86-93.

11. Burcombe RJ, Makris A, Richman PI i wsp. Evaluation of ER, PgR, HER-2 and $\mathrm{Ki}-67$ as predictors of response to neoadjuvant anthracycline chemotherapy for operable breast cancer. Br J Cancer 2005; 92: 147-155.

12. Sikov WM, Dizon DS, Strenger R i wsp. Frequent pathologic complete responses in aggressive stages II to III breast cancers with every-4-week carboplatin and weekly paclitaxel with or without trastuzumab: a Brown University Oncology Group Study. J Clin Oncol 2009; 27: 4693-700.

13. Goldhirsch A, Wood WC, Coates AS i wsp. Strategies for subtypes-dealing with the diversity of breast cancer: highlights of the St. Gallen International Expert Consensus on the Primary Therapy of Early Breast Cancer 2011. Ann Oncol 2011; 22: 1736-1747.

14. Sorlie T, Tibshirani R, Parker J i wsp. Repeated observation of breast tumor subtypes in independent gene expression data sets. Proc Natl Acad Sci USA 2003; 100: 8418-8423.

15. Rouzier R, Perou CM, Symmans WF i wsp. Breast cancer molecular subtypes respond differently to preoperative chemotherapy. Clin Cancer Res 2005; 11: 5678-5685.

16. Parker J, Prat A, Cheang M i wsp. Breast cancer molecular subtypes predict response to anthracycline/taxane-based chemotherapy. SABCS, 2009. http://www.abstracts2view.com/sabcs09/viewp.php?nu=p2019

17. Chang HR, Glaspy J, Allison MA i wsp. Differential response of triple-negative breast cancer to a docetaxel and carboplatin-based neoadjuvant treatment. Cancer 2010; 116: 4227-4237.

18. Fasching PA, Heusinger K, Haeberle L i wsp. Ki67, chemotherapy response, and prognosis in breast cancer patients receiving neoadjuvant treatment. BMC Cancer 2011; 11: 486.

19. Staver ME, Rutgers EJ, Rodenhuis S i wsp. The relevance of breast cancer subtypes in the outcome of neoadjuvant chemotherapy. Ann Surg Oncol 2010; 17: 2411-2418

20. Jung SY, Jeong J, Shin SH i wsp. The invasive lobular carcinoma as a prototype luminal $\mathrm{A}$ breast cancer: a retrospective cohort study. BMC Cancer 2010; 10: 664

21. Bergman L, van Dongen JA, van Ooijen B i wsp. Should tamoxifen be a primary treatment choice for elderly breast cancer patients with locoregional disease? Breast Cancer Res Treat 1995; 34: 77-83.

22. Bradbeer JW, Kyngdon J.: Primary treatment of breast cancer in elderly women with Tamoxifen. Clin Oncol 1983; 9: 31-34.

23. Mustacchi G, Ceccherini R, Milani S i wsp. Tamoxifen alone versus adjuvant tamoxifen for operable breast cancer of the elderly: long-term results of the phase III randomized controlled multicenter GRETA trial. Ann Oncol 2003; 14: 414-420. 
24. Smith IE, Dowsett M, Ebbs SR i wsp. Neoadjuvant treatment of postmenopausal breast cancer with anastrozole, tamoxifen, or both in combination: the Immediate Preoperative Anastrozole, Tamoxifen, or Combined with Tamoxifen (IMPACT) multicenter double-blind randomized trial. J Clin Oncol 2005; 23: 5108-5116.

25. Cataliotti L, Buzdar AU, Noguchi Si wsp. Comparison of anastrozole versus tamoxifen as preoperative therapy in postmenopausal women with hormone receptor-positive breast cancer: the Pre-Operative "Arimidex" Compared to Tamoxifen (PROACT) trial. Cancer 2006; 106: 2095-2103.

26. Ellis MJ, Ma C.: Letrozole in the neoadjuvant setting: the P024 trial. Breast Cancer Res Treat 2007; 105 Suppl 1: 33-43.

27. Mustacchi G, Mansutti M, Sacco C i wsp. Neo-adjuvant exemestane in elderly patients with breast cancer: a phase II, multicentre, open-label, Italian study. Ann Oncol 2009; 20: 655-659.

28. Ellis MJ, Suman VJ, Hoog J i wsp. Randomized phase II neoadjuvant comparison between letrozole, anastrozole, and exemestane for postmenopausal women with estrogen receptor-rich stage 2 to 3 breast cancer: clinical and biomarker outcomes and predictive value of the baseline PAM50-based intrinsic subtype - ACOSOG Z1031. J Clin Oncol 2011; 29: 2342-2349.

29. Gazet JC, Ford HT, Gray R i wsp. Estrogen-receptor-directed neoadjuvant therapy for breast cancer: results of a randomised trial using formestane and methotrexate, mitozantrone and mitomycin C (MMM) chemotherapy. Ann Oncol 2001; 12: 685-691.

30. Torrisi R, Bagnardi V, Pruneri G i wsp. Antitumour and biological effects of letrozole and $\mathrm{GnRH}$ analogue as primary therapy in premenopausal women with $\mathrm{ER}$ and $\mathrm{PgR}$ positive locally advanced operable breast cancer. Br J Cancer 2007; 97: 802-808.

31. Alba E, Calvo L, Albanell J i wsp. Chemotherapy (CT) and hormonotherapy $(\mathrm{HT})$ as neoadjuvant treatment in luminal breast cancer patients: results from the GEICAM/2006-03, a multicenter, randomized, phase-II study. Ann Oncol 2012; 23: 3069-3074.

32. Ambros TF, Reis IM, Bagga D i wsp. Neoadjuvant chemotherapy versus neoadjuvant hormonal therapy in postmenopausal women with ER-positive, HER2/neu negative locally advanced breast cancer. J Clin Oncol 2012; 30 (May 20, Suppl.): 595

33. Semiglazov VF, Semiglazov VV, Dashyan GA i wsp. Phase 2 randomized trial of primary endocrine therapy versus chemotherapy in postmenopausal patients with estrogen receptor-positive breast cancer. Cancer 2007; 110: 244-254.

34. Ellis MJ, Tao Y, Luo J i wsp. Outcome prediction for estrogen receptor-positive breast cancer based on postneoadjuvant endocrine therapy tumor characteristics. J Natl Cancer Inst 2008; 100: 1380-1388.

W dniach 5-7 września 2014 r. odbędzie się w Ustce

Konferencja naukowo-szkoleniową „XI Usteckie Dni Onkologiczne”

Przewodniczący Komitetu Organizacyjnego Zoran Stojčev

Główne tematy:

- Genetyka w służbie chirurgii onkologicznej

- Powikłania chirurgiczne i onkologiczne leczenia nowotworów

—Sesja dla pielęgniarek: Rak piersi — współczesne wyzwania i nadzieje

Miejsce obrad:

Hotel Royal Baltic, Ustka, ul. Wczasowa 26

Informacje:

tel./fax 059/8460368, 512004399, 601490560,

e-mail: onkoustka@wp.pl, http://www.onko.ustka.pl 